\title{
Study on the Mechanism of Increasing Tuition Fees in American High-level Private Universities
}

\author{
Changming Liu \\ Yangtze University College of Engineering and Technology.Jingzhou434020China \\ 945765374@qq.com
}

Keywords: United States; High-level private universities; Tuition fees; Rising mechanism

\begin{abstract}
In order to draw lessons from the experience of multi-channel funds raised by high-level private universities in the United States, promote the healthy development of private universities in China, and use literature research and comparative research methods to study the composition of tuition fees and the mechanism of tuition increase in high-level private universities in the United States. The study found that the funding for running high-level private universities in the United States is mainly composed of tuition fees, government funding, donation income, and school investment operating income. Tuition income generally accounts for $30 \%$ to $40 \%$ of the total annual funding; the tuition fees of high-level private universities in the US are generally high. In public universities, the increase in tuition fees is 2 to 3 percentage points higher than the average growth rate of consumer prices. The conclusion of the study is that the pressure for increasing the cost of running a school is the mechanism for inducing the increase of tuition fees. The school board has the authority to approve the tuition fees as a decision-making mechanism for the increase of tuition fees. The examination of the Higher Education Commission is an examination and approval mechanism for the increase of tuition fees. This conclusion has important theoretical guidance significance and realistic reference value for Chinese private universities to open up diversified financing channels.

As we all know, the tuition fees of American private universities are much higher than those of public universities, and the rise in tuition fees of high-level private universities is much easier than that of public universities. How did the tuition fees of high-level private universities in the US rise? This article does some research on this topic.
\end{abstract}

\section{One, the Status Quo of the Development of Private Universities in the United States}

The development history of American private universities is far longer than that of the United States. Originally in the British colonial period, in 1636, the British missionaries set up the New Civic Academy. Later, Harvard College was renamed Harvard College because of the donation of Harvard. The school was 140 years older than the United States. After the New Civic College, Yale University, University of Pennsylvania, Princeton University, Columbia University, Brown University, and Dartmouth College were successively founded. The above seven universities were established before the founding of the United States, and they are both older than the United States. The decision of the Dartmouth College case opened the way for the development of private universities in the United States, and also promoted the development of American State University and local colleges. Although the development of private universities in the United States does not have a long history of private universities in Europe, the quality and reputation of private universities in the United States is higher than that of European universities and they become the most advanced private higher education institutions in the world. By the end of the 20th century, the number of private institutions of higher learning that had the right to award degrees in the United States had grown to 17,720 , and there were only 1,420 public colleges and universities, and private colleges and universities exceeded 300 public colleges and universities (1). By 2013, there were a total of 3,039 four-year colleges with a degree-granting authority in the United States, of which 691 were public institutions and 2,348 were private institutions (2) And the quality of running a private university has always been at the leading level. Whether it is the American University Rankings, the 
European University Rankings, or the Chinese University Rankings, the US private universities are among the top lists. If we say that the top 50 universities in the world's university rankings are called high-level universities, then the private universities in the United States are the vanguards of high-level universities in the world, leading the development of global higher education because of the private universities in the United States. In particular, the "Ivy League" affiliate school is among the top 20 universities in the world.

\section{Second, the Funding Structure of High-level Private Universities in the United States}

One is tuition income. The tuition of high-level private universities in the United States is an important part of the school's expenses for running schools, which generally account for $30 \%$ to $40 \%$ of the total school funding. In the academic year of 1980-1981, private tuition fees for education in the United States accounted for $36.6 \%$ of the total, $40.4 \%$ for the academic year 1990-1991, and 32.5\% for the 2003-2004 academic year. (3) However, tuition fees Income still occupies a high percentage of all school income. In the United States, private universities have the right to determine the tuition fees based on the cost of education and market acceptance, while public universities do not have such authority. Tuition fees for higher-level private universities are higher than those for public universities of the same grade. The higher the level, the higher the reputation for better private universities and the higher the tuition fees. For example, in 2004-2005, the average public school fee in the United States was 5038 US dollars, while the average private university has reached 18,838 US dollars, Harvard University, Princeton University, each student charges more than 25,000 US dollars per year. In 2018, the tuition fee for Columbia University was 57,208 dollars, the University of Chicago was 54,825 dollars, and the University of Pennsylvania was 53,534 dollars.

The second is government funding. Public funding for high-level private universities in the United States comes from federal, state, and local governments. The U.S. government grants to private universities account for about $17 \%$ of the total annual funding for private schools, and is mainly funded by the federal government, followed by state funding, and local government funding is less. Funds allocated by the federal government include loan and contract payments, grants, and funding from research and development centers. Most of the federal government's grants are scholarships for students, and some research-based private universities and public universities receive research funds allocated by the federal government. State government grants to private universities mainly provide students with scholarships, as well as a small amount of loans and contract payments. In 2012, Harvard University received a total government grant of 688 million U.S. dollars, of which the majority came from the federal government, mainly including the Ministry of Health, the National Natural Science Foundation, and the Ministry of National Defense. The Ministry of Health allocated $78.4 \%$ of the total amount of funding. (4). There are also funding from the Ministry of Energy, the National Aeronautics and Space Administration, the Ministry of Education, the Environmental Protection Agency, the Ministry of Foreign Affairs, and the International Development Agency. Government funding accounts for about $20 \%$ of Harvard's annual total funding.

The third is all kinds of donations. Donation income is one of the important sources of funds for running high-level private universities in the United States. The proportion of donated income accounts for $8 \%$ to $13 \%$ of total education funds, and some schools account for more than $13 \%$. For example, about $21 \%$ of Cornell's budget comes from various donations. Harvard University's total revenue in 2008 was US\$ 3.4 billion, of which donation income accounted for 34\%. The donation income mainly comes from the alumni donations, foundation donations and commercial donations. According to statistics, there are 4,500 foundations in the United States that are engaged in donations to promote education development. The most famous ones are the Carnegie Foundation Council and the George Pippa Education Foundation. These foundations donate to different degrees. However, alumni donation is the main channel for private universities to obtain donations. As of 2016, Harvard's endowment fund reached US\$356.6574.3 billion, ranking first among private universities in the United States. Yale University ranked second, with endowment funds reaching 
US\$254.13149 billion, Stanford University with US\$22.3971 billion, Princeton University with US\$217.03 million, and US\$500 million. The provincial college of technology is 131.81515 billion U.S. dollars, and the University of Pennsylvania is 107.15364 billion U.S. dollars (5).

The fourth is school investment income. The use of scientific research and patent financing by private universities in the United States is a common practice. The use of scientific research funds to raise funds and school-enterprise cooperation to obtain funding income account for about $21 \%$ of current high education fees in the United States. There is also income from school-run enterprises, such as school-based housing, catering, school stores, and entertainment in Cornell that account for $10 \%$ of budget revenue (6).

\section{Third, The Higher level of Tuition Fees in Private Universities in the United States}

The Pressure of Increasing the Cost of Running a School is the Induction Mechanism of Rising Tuition Fees. The main incentive for high-level private universities to raise tuition fees is the rising cost of running schools. In 1967, William Bowen wrote that during the 60 years from 1905 to 1965, the average annual per capita education cost of high-level private universities in the United States was higher than the average growth rate of consumer prices by 2 to 3 percentage points. This was partly due to the increase in costs. The increase in the degree of professionalization of knowledge and the increase in emerging research areas are also attributed to the increased emphasis on postgraduate training and scientific research. For example, during the academic year from 1966 to 1967 to 1997 to 1998, Cornell University's annual tuition fee growth rate averaged 2.8 percentage points higher than the consumer price growth rate for the same year. However, from 1966 to 1967 to 1979 to 1980 academic year, the proportion of tuition and miscellaneous fees to the annual income of middle-income families remained basically between $26 \%$ and $28 \%$. Since 1980 , Cornell University's tuition increase rate has begun to exceed the annual growth rate of US households. From 1980 to 1981 to 1992 to 1993, the proportion of tuition fees in household income rose from $28 \%$ to $49 \%$. The level of tuition at the University of Seoul and the income level of middle-income families in the United States remain relatively stable. In spite of the rapid increase in tuition fees, the proportion of tuition fees in the total funds for running schools is not very large. For the 1997-1998 school year, only about 33\% of the budget revenue on Cornell's main campus in Issegge came from tuition fees and miscellaneous fees. In fact, in the United States, the rate of increase in tuition fees for high-level private universities is basically faster than the rate of inflation. For example, in the academic year 2000-2001 to 2001-2002, eight "Ivy" universities and MIT, Duke University, and John Hopkins University, Northwestern University, University of Chicago, Stanford University, and California Institute of Technology, as well as a number of private high-level liberal arts colleges, have tuition fees rising by about 2 percentage points above the inflation rate (7).

Why do private university administrators raise their tuition every year? Because private university administrators are under budget pressure. When the budget is tight, they face difficult choices. If they propose to reduce the budget or reduce the increase in teacher pay, they will be condemned by teachers and lose the support of teachers, which makes it difficult to work and will also affect their re-election. Opportunity. Therefore, they only have to explain to the board of directors the reasons for the need to increase tuition fees to ensure the quality of teaching. Otherwise, they will not only be accused by the teachers but may even be accused. Therefore, school administrators would rather reduce budget pressure by raising tuition fees and would not risk losing the support of teachers (8).

The School Board has the Right to Approve the Tuition Fees as a Decision Mechanism for the Tuition Increase. The board of directors of high-level private universities in the United States has ultimate authority over all university affairs. Most of the board members are university alumni. All alumni directors hope that the university will flourish. Although they have the final voting power to set the university budget and tuition fees, they are more respectful and tolerant of university administrators. They often give universities considerable room for free management in terms of budget and tuition fees, that is, university administrators. The budgets and tuition fees that have been set are basically approved by the board of directors. In contrast, the directors of public 
universities are often appointed by local administrators or state legislatures, and their power in setting budget and tuition fees is limited. In some states, tuition fees and grants for state universities are approved by local governments and legislatures. In other states such as New York, the State University Board of Directors has the final say on the tuition standards, and the grants to state universities are determined by the local government and the legislature. Although the public university board has the right to decide on tuition fees, they still have to look at the attitude of the government and the legislature. If the government and the legislature don't agree that the tuition fees will rise, public university directors will not increase tuition fees (9). This is the institutional factor that American private universities have higher tuition fees than public universities and that private university tuition increases are easier than public universities.

The Review of the Higher Education Commission is the Approval Mechanism for the Increase in Tuition Fees. In the United States, there is not a national higher education system managed by the federal government. The federal government has never undertaken direct obligations to support the development of higher education. According to the education management system of decentralization of education, the federal government does not bear the main responsibility for the development of higher education. Therefore, the federal school's tuition standards, the federal government will not be questioned, there is no question of approval. Tuition fees for private universities are subject to approval by the U.S. Higher Education Commission. According to U.S. News \& World Report, the U.S. Higher Education Commission said at the end of 2017 that the committee had approved all applications for 286 private universities to increase tuition fees and other fees for the 2017-2018 school year. The approved colleges and universities account for $16 \%$ of 1,652 private universities nationwide, which will bring a net income of $\$ 74$ million to the university. At this point, tuition fees for the top 50 private universities in the United States will increase by an average of $3.6 \%$ (10).

\section{References}

[1] X.h.Zhou and L. Chen. The Comparison of the Positioning of Private Universities in US and Japan and the Higher Education Institutions in China in Higher Education. Polytechnic Higher Education Research, 2003 Vol.22 No.3P.19.

[2] https:/ /nces.ed.gov/programs /digest /d15/tables /dt15-105.50.asp.

[3] Y.d. Sun .The source of funding for higher education in the United States and its inspiration [J]. Modern Education Management, 2009, No. 7, pp. 98-99.

[4] Y.A. Zhao. Harvard University's research funding sources and funding management.

http://www.jysj.cee.edu.cn/shenjikanwu/wenzhangjingxuan/2017-01-05/2543.

[5] Look at the richest universities in the United States from the Endowment Fund. www.liuxue.com .2017.08.11.

[6] [U.S.] Ronald G. Ailenberg, translated by Cui Yuping. American University Tuition Fees. Beijing. Beijing Normal University Press, 2008, pp. 5.

[7] [United States] Ronald G. Ehrenberg, translated by Cui Yuping. American University Tuition Fees. Beijing. Beijing Normal University Press, January 2008, 1st edition.

[8] Ronald G. Ailenberg, translated by Cui Yuping. American University Tuition Fees. Beijing. Beijing Normal University Press, 2008, pp. 25.

[9] Ronald G. Ailenberg, translated by Cui Yuping. American University Tuition Fees. Beijing. Beijing Normal University Press, 2008, pp. 24.

[10] Are the 286 US private universities soaring in tuition fees? Xiaoxiang Morning News. December 08, 2017. 